\title{
SEKILAS TENTANG TOKOH BIMA
}

\section{Oleb : Gunadi}

\section{Pendahuluan.}

Tokoh Bima di Jawa selama ini dikenal dalam tiga bentuk penggambaran, yaitu

1. Bima yang digambarkan sebagai arca batu.

2. Bima yang digambarkan dalam relief pada candi.

3. Bima yang digambarkan dalam cerita wayang atau kitab Dewaruci.

Baik Bima sebagai arca, dipahatkan pada relief, maupun Bima yang terdapat di dalam cerita wayang, memiliki persamaan - persamaan dan diperkirakan berasal dari satu periode.

Seperti telah kita ketahui Dr. W.F. Stutterheim di dalam bukunya yang berjudul Studies in Indonesian Archaeology telah menguraikan secara luas tentang tokoh Bima. Stutterheim antara lain mengatakan bahwa arca Bima yang digambarkan dengan tubuh yang stram dan memakai upawita ular adalah identik dengan Bima Bhairawa dalam agama Ciwa. yaitu salah satu aspek dari Ciwa (Stutterheim, 1956:116 -- 7).

Munculnya pemujaan kepada tokoh Bima ini kira-kira pada masa akhir pemerintahan kerajaan Majapahit, yakni sekitar abad XV Masehi. Hal ini terlihat pada arca Bima yang ditemukan di Pesanggrahan Mangkunegaran, Tawangmangu. Pada bagian belakang arca tersebut terdapat inskripsi yang oleh Stutterheim dibaca Bhima Gana Rama Ratu. Selanjutnya inskripsi tersebut diinterpietasikan sebagai candra sengkala yang berarti angka tảhun 1365 Gaka atau 1443 Masehi (Stutterheim, 1956 : 108). Berdasrkan data di atas, maka arca-area Bima yang lain seperti yang ditemukan di kompleks candi Ceto dan Penampihan (lereng gunung Wilis) diperkirakan sejaman dengan area Bima yang ditemukan di kompleks candi Sukuh.

Di atas telah disebutkan bahwa Bima merupakan salah satu aspek dari Ciwa. Tetapi penonjolan tokoh Bima ini baru muncul pada masa akhir periode Majapahit. Telah kita ketahui pula bahwa figur Bima munculnya bersamaan dengan datangnya pengaruh Hindu ke Indonesia.

Suaka Peninggalan Sejarah dan Purbakala Propinsi Jawa Tengah. 


\section{ARCA-ARCA DAN RELIEF BIMA.}

Arca-arca ataupun relief Bima antara lain terdapat di kompleks candi Sukuh. Arca tersebut sekarang berada di Taman Partini, Solo. (Foto : 1).

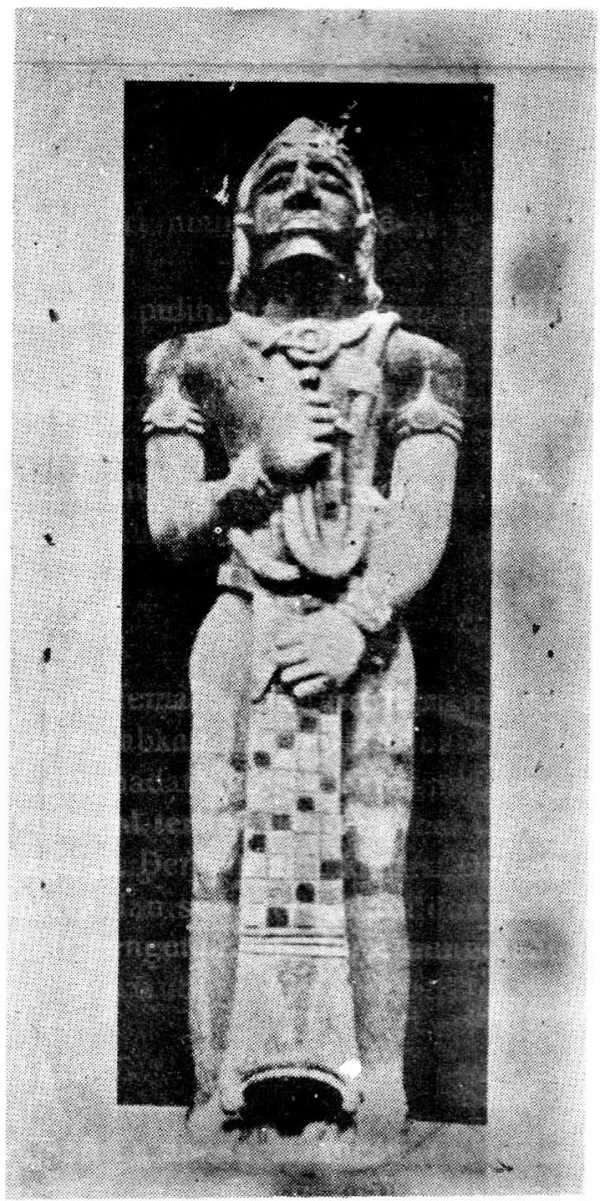

Arca Bhima dari Candi Sukuh dahulu berada di Taman Partini, Solo. (Reproduksi dari Studies in Indonesian Archaeology). 
Arca ini berdiri di atas sebuah lapik, pada kepala bagian belakang terdapat kucir yang melengkung (gelung). Muka berkumis, kedua tangan disamping badan, dan tangan memegang ular yang meliliti badannya. Oleh penduduk setempat arca ini disebut Bimo atau Bima. Untuk relief Bima, sampai sekarang masih dapt dilihat di kompleks candi Sukuh pada teras ketiga sisi utara (foto : 2). Sedangkan arca Bima di candi Ceto digambarkan de-

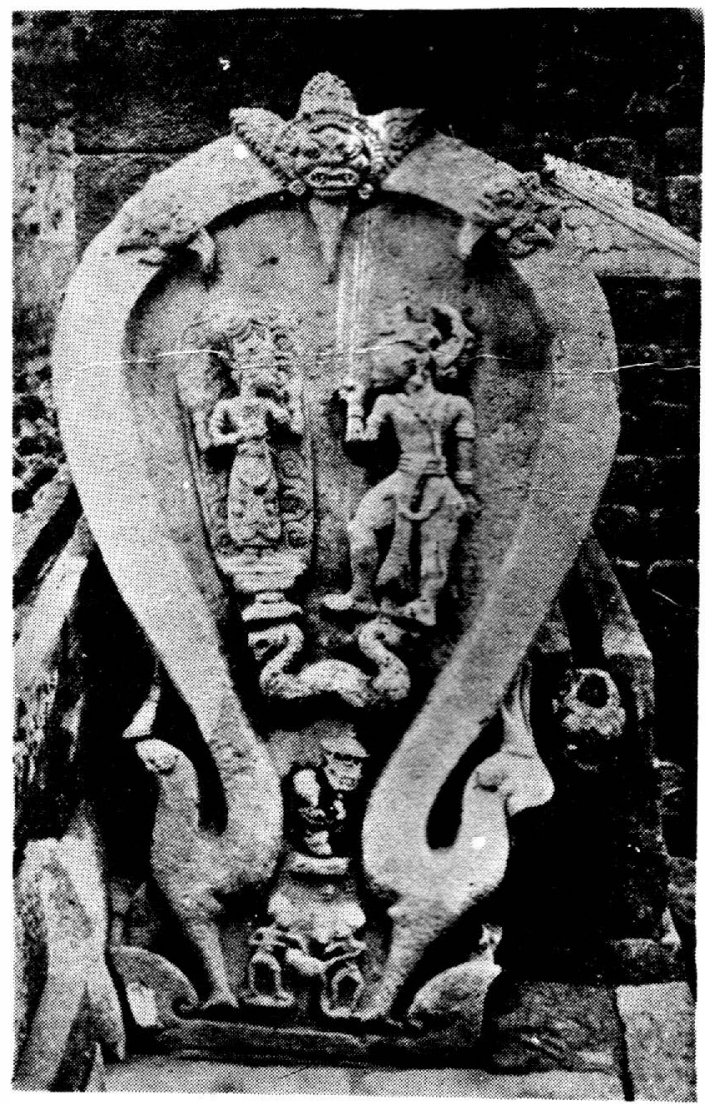

Keterangan gambar :

Relief Bhima dari Candi Sukuh.

(Reproduksi dari Study in Indonesia Archaeology). 
ngan mata melotot, hidung besar bibir tebal dan kumis melengkung. Posisi arca jongkok dengan pakaian bermotif poleng (foto : 3 ).

Di Penampihan lereng gunung Wilis bagian tenggara, ditemukan pula bangunan berteras mirip dengan candi Sukuh. Pada kompleks tersebut

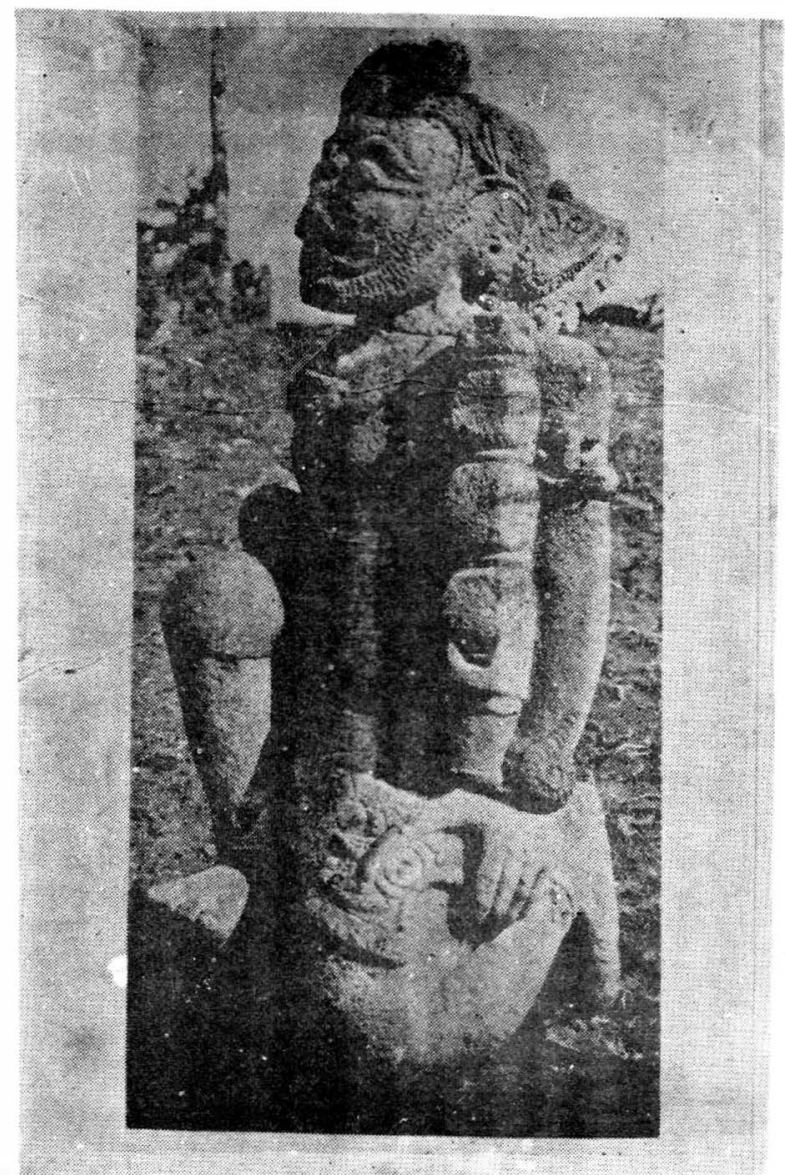

Archa Bhima dari Candi Ceto.

(Reproduksi dari Studies in Indonesia Archaeology). 
ditemukan pula arca-arca Werkudoro. Arca ini berdiri di atas bantalan lotus dengan mahkota di kepala, ular meliliti badan dan membawa sebuah gada. Arca Bima yang lain ditemukan di lereng gunung Kawi, bagian bawah arca tersebut telah rusak, memakai upawita ular, rambut digelung dan mata menakutkan, hidung dan kumis telah rusak (Stutterheim, 1956 : $109-110)$.

\section{TOKOH BIMA DALAM PENTAS WAYANG.}

Di dalam cerita pewayangan, Bima adalah putera kedua dari lima bersaudara Pendawa. Diceritakan pula bahwa tokoh ini pada waktu lahir kedunia dalam keadaan bungkus, yakni seluruh badannya terbungkus oleh caul. Oleh karena itu sejak lahir ia dianggap mempunyai suatu kesaktian yang luar biasa, maka caul tersebut tidak dapat dibuka oleh siapapun. Akhirnya Bima dalam keadaan terbungkus dibuang ke tengah hutan Gandamaylt. Di tengah hutan itulah seekor gajah yang bernama Sena dapat merobek caul tersebut, dan keluarlah sang Bima. Gajah Sena adalah seekor gajah yang diturunkan dari kahyangan.

Wayang atau sering disebut dengan drama tradisional, adalah hasil seni Indonesia asli. Wayang sudah ada sejak pemerintahan raja Jayabaya di Kediri. Cerita-cerita diambil dari kitab Bharatayuda dan Ramayana. Pada masa itu bentuk wayang diambil contoh dari relief candi Panataran. Kemudian pada masa kejayaan raja Majapahit seni wayang mengalami perkembangan di dalam pementasannya, yaitu dengan menggunakan panel-panel dari kain yang menggambarkan adegan-adegan tertentu. Wayang semacam ini disebut wayang beber, sebab panel kain yang melukiskan suatu adegan tersebut hanya dibeberkan atau dipaparkan saja. (Sri Mulyono. 1978:70 -- 1).

Bentuk wayang beber di atas menurut hemat kami mirip dengan cerita pada relief candi yang juga terdiri dari panel-panel yang melukiskan suatu adegan tertentu. Seni wayang beber sampai sekarang masih dapat ditemukan di pelosok Jawa Timur. Setelah Islam berkembang pesat di tanah Jawa wayang mengalami perkembangan pula yaitu dibuat dari kulit kerbau (Sajid, 1958; 62).

Bima atau Werkudara di dalam pewayangan digambarkan dengan tubuh kekar, mata melotot dan pada kedua tangannya mempunyai kuku pancanaka. Diceritakan pula bahwa satria Pandawa itu berbudi luhur, cinta kebenaran dan setia kepada keutamaan. Di lingkungan keluarga dan ne- 
gerinya, Bima merupakan benteng pertahanan, sebab disamping kekuatan tenaga dan kecerdasan berpikir Bima juga mempunyai beberapa ilmu kesaktian antara lain aji bandung bandawasa, wungkal bener, blabak pengantolan yang kesemuanya itu dapat membentengi keselamatan hidupnya di dunia fana. Namun demikian suatu ketika datanglah rasa kecewa yang mengganggu sang/Bima Pangkal kekecewaan itu ialah karena ia belum memiliki Tirta Pawitradi, yaitu air yang dapat mensucikan diri atau ilmu kesempurnaan hidup. Rasa kecewa itu tiba-tiba menjadi suatu citacita yang teguh, dengan diam-diam maka pergilah sang Bima mencari seorang guru yang dapat menunjukkan dimana letak Tirta Pawitradi (Siswo Harsoyo, $1966: 18$ - 22).

Akhirnya Bima mendapatkan seorang guru yakni Resi Drona. la berkenan memberi wejangan penunjuk jalan kepada sang Bima dengan saransaran yang harus diindahkan. Berkat ketaatan sang Bima atas wejangan Resi Drona tanpa menghitung kesukaran dan pengorbanan, akhirnya iapun dapat bertemu dengan guru sejati. Guru sejati inilah yang dimaksud dengan Tirta Pawitradi. Di dalam pewayangan guru sejati ini terkenal dengan nama Dewa Ruci atau Sang Hyang Wenang (Siswo Harsoyo. $1966: 18$ - 22).

Pengorbanan sang Bima selama mencari Tirta Pawitradi ini antara lain harus membongkar Gunung Reksamuka yang dijaga oleh dua Raksasa Godaan yang lain dihadangnya sang Bima di tengah perjalanan oleh ke. empat "saudara tunggalnya", yakni Bayu Kibara, Bayu Kanitra, Bayu Anras dan Bayu Langgeng agar mengurungkan niatnya. Gunung Reksamuka maupun keempat makhluk saudara tunggal sang Bima di atas merupakan suatu ungkapan filosifis yang sangat tinggi.

Di atas telah dikatakan bahwa dalam pengembaraan pertama, sang Bima harus membongkar Gunung Reksamuka. Makna dari ungkapan ini menurut Ki Siswo Harsoyo bahwa kata Reksamuka berasal dari kata Reksa dan Muka. Reksa berarti menjaga dan Muka berarti bagian depan yang tampak atau sifat lahiriah (Siswo Harsoyo, 1966 : 18 - 22). Dalam hal ini sang Bima harus dapat mengatasi atau menjaga sifat-sifat lahiriah yang dimiliki selama ia masih hidup di dunia. Ungkapan kedua. yakni dalam perjalanan menuju kelaut Selatan untuk mencari Tirta Pawitradi, Bima dihadang lagi oleh keempat saudara kembarnya. Makna dari ungkapan di atas ialah melambangkan empat nafsu yang dimiliki oleh manusia.

Bayu Kanitra yang dilambangkan dengan seekor gajah adalah lambang nafsu aluamah yaitu nafsu makan dan minum. Bayu Anras yang dilam- 
bangkan dengan raksasa adalah lambang nafsu amarah. Bayu Kinara yang dilambangkan dengan kera adalah lambang nafsu Supiah atau keinginan yang serba baik. Yang keempat ialah Bayu Langgeng yang dilambangkan dengan Dewa adalah lambang nafsu mutmainah yaitu tingkah laku yang sumuci-suci.

Demikianlah gambaran keempat saudara tunggal, yaitu lambang dari keempat nafsu yang selalu mengikuti jalan hidup dan hidup bersatu dengan diri manusia. Di atas telah disinggung juga bahwa Tirta Pawitradi terletak di dasar laut Selatan. Ungkapan ini juga merupakan ungkapan filosofis, dasar laut itu adalah perumpamaan dari dasar hati sanubari manusia. Di sinilah sang Bima dapat bertemu dengan Dewa Ruci Sang Guru Jati atau sering disebut Sang Hyang Wenang, kemudian sujudlah sang Bima kepada Dewa Ruci.

Pemujaan Bima atu sering disebut dengan Bima Cultus ini muncul kurang lebih awal abad XV $M$. Masa-masa ini adalah masa mundurnya kerajaan Hindu di Jawa/Jawa Timur yaitu Majapahit dan mulai berkembangnya pengaruh Islam di Pulau Jawa. Kebudayaan Islam sebetulnya jauh sebelum abad XV $M$ telah datang ke Indonesia atau Jawa. Hal ini dapat dilihat dari temuan-temuan arkeologis Islam antara lain makam Fatimah binti Maimun yang berangka tahun $1082 \mathrm{M}$

Di dalam kesusasteraan dan cerita pewayangan Bima digambarkan sebagai tokoh yang telah mencapai kesempurnaan. Karena hanya dialah yang berhasil menemukan Tirta Pawitradi yaitu air kesucian. Ilmu kesempurnaan hidup semacam ini di dalam kesusasteraan jaman Islam dapat dilihat pada suluk Malang Sumirang yang berisi tentang pengagungan orang yang telah mencapai kesempurnaan hidup. Orang yang telah lepas dari ikatan-ikatan Syariah dan berhasil bersatu dengan Tuhan.

Dari uraian-uraian di atas, maka dapat disimpulkan disini bahwa pemujaan kepada tokoh Bima seperti terlihat pada arca-arca Bima yang telah disebutkan pada bagian terdahulu adalah pemujaan kepada tokoh yang telah mencapai kesempurnaan. Pertemuan antara sang Bima denganSang Dewa Ruci yang telah disebutkan di atas sebetulnya merupakan lambang "Warangkamanjing curiga", yang berarti bersatunya Bima dengan zat Tunggal/Tuhan. Disinilah munculnya konsepsi monotheisme pada masa itu. Jadi pemujaan kepada tokoh Bima ini bukanlah pemujaan kepada roh nenek moyang ataupun seorang tokoh penting seperti Raja, melainkan pemujaan kepada dzat Tunggal yang digambarkan dengan Dewa Ruci dalam pewayangan atau pemujaan kepada Tuhan Yang Maha Esa. 
Hal tersebut diperkuat pula dengan bukti-bukti penulisan pada abad XV M antara lain Kitab Dewa ruci yang ditulis pada masa akhir pemerintahan Majapahit, serta kitab-kitab lain yang digunakan sebagai sumber cerita wayang. Di dalam lakon pewayangan sering dilukiskan dewa-dewa berbuat kesalahan dan dapat dikalahkan oleh mahluk dunia. Hal ini menunjukkan bahwa dewa-dewa tersebut bukanlah yang Maha Kuasa atau Tuhan Yang Maha Esa, tetapi merupakan titah pula.

Atas dasar data-data di atas, maka timbullah suatu pemikiran yang berbeda dengan apa yang telah diuraikan oleh W.F. Stutterheim dalam Studies in Indonesian Archaeology. Tokoh Bima yang muncul pada abad XV M adalah bukti semakin kuatnya konsep-konsep Islam yang masuk ke dalam masyarakat Hindu yang sudah mulai terdesak. 


\section{DAFTAR P U S TAKA}

S ajid, R.M. 1958. Bauwarna Wayang, P T. Pertjetakan Republik Indonesia, Jakarta.

S iswoharsoyo, 1966. Tafsir Kitab Dewarutji, P T. Jaker, Yogyakarta

S ri Mulyono, 1978. Wayang Asal-U sul, Filsafat dan Masa Depannya, Gunung Agung, Jakarta.

S tutterheim W.F. 1956. An A ncient Javanese Bhima Cultus, S tudies In Indonesian Archaeology; The Hague-Martinus Nijhoff. 